\title{
河川下流域の土砂動態に着目した 富栄養化湖沼の流入負荷特性に関する検討 STUDY ON POLLUTANT LOAD INTO A EUTROPHIC LAKE WITH ATTENSION TO SEDIMENT TRANSPORT IN A LOWER REACH OF RIVER
}

\author{
二瓶泰雄 ${ }^{1} \cdot$ 大関雅丈 $^{2} \cdot$ 福地正宗 $^{3}$ \\ Yasuo NIHEI, Masatake OOZEKI and Masatoshi FUKUCHI
}

\author{
${ }^{1}$ 正会員 東京理科大学助教授 理工学部土木工学科（广 278-8510 千葉県野田市山崎 2641) \\ ${ }^{2}$ 正会員 日揮(姝)（广100-0004 東京都千代田区大手町 2-2-1) \\ ${ }^{3}$ 学生員 東京理科大学大学院 理工学研究科土木工学専攻修士課程 (₹ 278-8510 千葉県野田市山崎 2641)
}

\begin{abstract}
Monitoring of pollutant load in an influent river flowing into a eutrophic lake is not generally conducted at the mouth of the river but at stations just upstream from the river mouth. To compare the pollutant load at the upstream station and the river mouth, we have conducted continuous measurements and numerical computations of pollutant load with special attention to the sediment transport in the lower reach of river. The observed data indicate that the appreciable differences of SS fluxes at the upstream stations and river mouth appear under rainy conditions while the yearly-averaged SS flux at the upstream station is almost comparable to that at the river mouth. It should be also noted that the numerical accuracy of sediment transport may be strongly dependent on the treatment of spatial variations of an erosion rate of sediment and evaluations of bottom friction.
\end{abstract}

Key Words: pollutant load, eutrophic lake, sediment transport, lower reach of river, pick-up rate

\section{1. 序論}

富栄養化が著しい湖沼における水環境管理を遂行 する上では , 流域からの流入負荷を適切にモニタリ ング及びモデリングすることは極めて重要である11 流域から河川経由で湖沼へ流入する総負荷量をモ二 タリングする上では, 河川と湖沼の接続点（以下， 単に接続点と呼ぶ）において, 流量や水質濃度を実 測することが必要となる2l．

この接続点は, 当然, 湖沼の水位変化や水質の影 響を直接的に受けるため, 通常，湖沼影響の小さい 上流側の地点 (以下, 一般観測点と呼ぶ）が観測地 点として選定される . 接続点と一般観測点における 流入負荷が同一になれば問題ないが, 横流入がない 場合でも，両地点の負荷に大きな違いが生じるケー スが報告されており，谷の傾向は懸濁態物質の輸送 量において顕著となる ${ }^{3)}$ ４）．現状では，実測デー タが限られているため，一般観測点と接続点を含む 河川下流域における流入負荷特性が, 一降雨イベン 卜 , 月，年などの樣々な時間スケールでどのように なるかは不明な点が多い.さらに, これと対応した 流入負荷のモデリング技術については, 兴の実態が 未解明なため，検討すべき課題が多々存在する .

本研究では, 富栄養化湖沼の流入河川下流域にお
ける流入負荷特性の実態を把握するとともに，光の モデリング手法について検討する .ここでは，負荷 量の大部分を占め, かつ, 栄養塩回帰を引き起こす 懸濁態物質 ${ }^{5}$ ，，6) の動態 (土砂動態) に着目して流 入負荷特性を検討する。まず, 富栄養化湖沼として 有名な千葉県手賀沼 ${ }^{1)}$ に流入する大堀川を対象とし て，自記式濁度計等を用いて長期間にわたる土砂輸 送量モニタリングを実施する。観測データより，一 降雨イベント，月，年という樣々な時間スケールを 対象として, 上流側の一般観測点と下流側の接続点 の土砂輸送量を比較する．次に，下流域の物質循環 を考慮した流入負荷のモデリング手法を検討するた めに, 河床における底質巻上げ量の取り扱いに着目 した土砂輸送計算を同じ大堀川において実施する．

\section{2. 現地観測の概要}

観測サイトである大堀川は, 流域面積が $31 \mathrm{~km}^{2}$, 流路延長が $12.9 \mathrm{~km}$ である 流域の約 8 割が市街地で あり，流域の都市化に伴う過剩な污濁物質流入が手 賀沼の水質悪化の要因であると指摘されている7 ${ }^{71}$.

観測地点は，図-1に示すように, 大堀川下流域 3 地点 (Stns.1〜3) , 湖沼 1 地点 (Stn.4) とする.Stns.1 と 2 は, 河川と湖沼の接続点である $\operatorname{Stn} .3$ から上流 


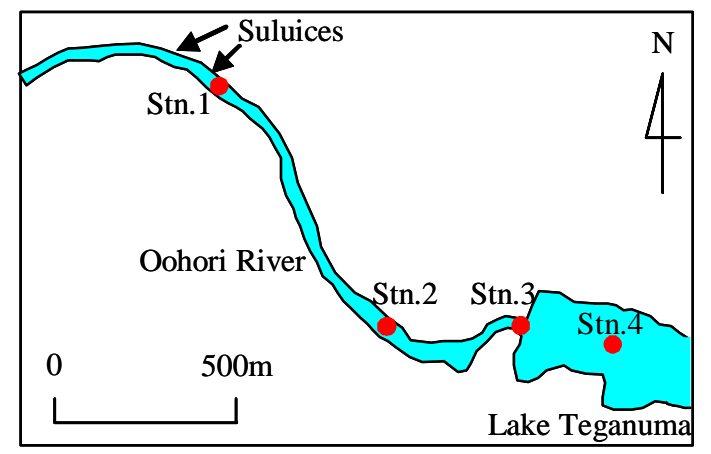

図-1＼cjkstart観測サイト及び観測地点

側 $1.5 \mathrm{~km} ， 0.6 \mathrm{~km}$ に光れ攵れ位置し，Stn.1 は一般観 測点に相当している この観測は 2005 年 6 月 3 日か ら開始し，Stn.2 のみ同年 7 月 28 日に終了し，光の 他の 3 地点では現在でも継続している，本論文では， 2006 年 6 月 3 日までの 1 年間の観測結果を解析対象 とする．観測項目は水位と濁度であり，乥れ光れ自 記式水位計 (Diver, Eijikelkamp 社製) とワイパー付 き光学式濁度計 (Compact-CLW,アレック電子(姝)製) を用いる.これらの自記式測器の計測時間間隔は 5 分もしくは 10 分とする.

土砂輸送量を算出するためには, 水位と濁度を光 れ光れ流量と土砂濃度 (SS) に変換する必要がある．
流量を得るためには，まず, Stn.1における水位デー タ及び別途求められた $H-Q$ 曲線から Stn.1における 流量を算出する . 光こで得られた流量值及び水位観 測値を用いて，連続式により Stn.1 から下流側に位 置する Stn.3 の流量を算出する．また，濁度から SS に換算するために, 降雨時 (2005 年 7 月 26 日 5 10 時）に表層バケツ採水を実施した．关のサンプル水 に対して SS をガラス纎維ろ紙法8)により求め，SS と濁度の検定曲線を算出する．

\section{3．観測結果と考察}

\section{( 1 ) SS の時系列変化}

1 年間にわたる大堀川の流況や SS 環境の全体像 を把握するために，流量 $Q$ (Stn.1) 及び SS (Stns.1， 3) の時間変化を図-2に示す. 図中には，1 時間移 動平均値が示され，また特徵的な降雨イベント時を 矢印で図示する．また同図（b）と（c）の縦軸の目 盛が異なることに注意されたい，まず，流量 $Q$ に関 しては，平常時にはおおよ光 $1.0 \sim 2.0 \mathrm{~m}^{3} / \mathrm{s}$ となって いる．降雨イベント時には流量が大きく増加し， $20 \mathrm{~m}^{3} / \mathrm{s}$ を超える降雨イベントも発生している (降雨 イベント (2)，(4)）.また，2005年 $11 ， 12$ 月及び 2006 年 4,5 月には大きな出水は生じていない .

(a) $Q$ at $\operatorname{Stn} .1\left[\mathrm{~m}^{3} / \mathrm{s}\right]$

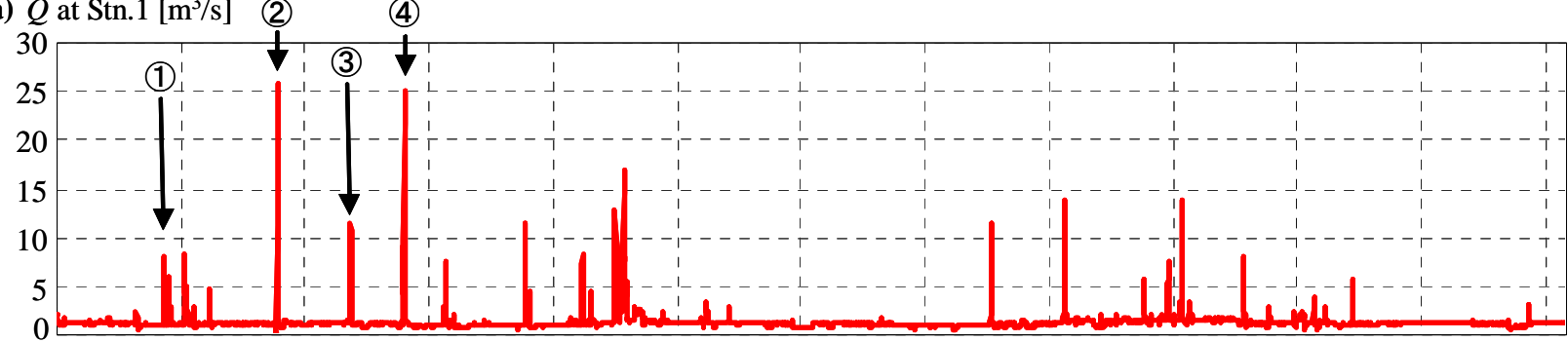

(b) $\mathrm{SS}$ at Stn.1 [mg/l]

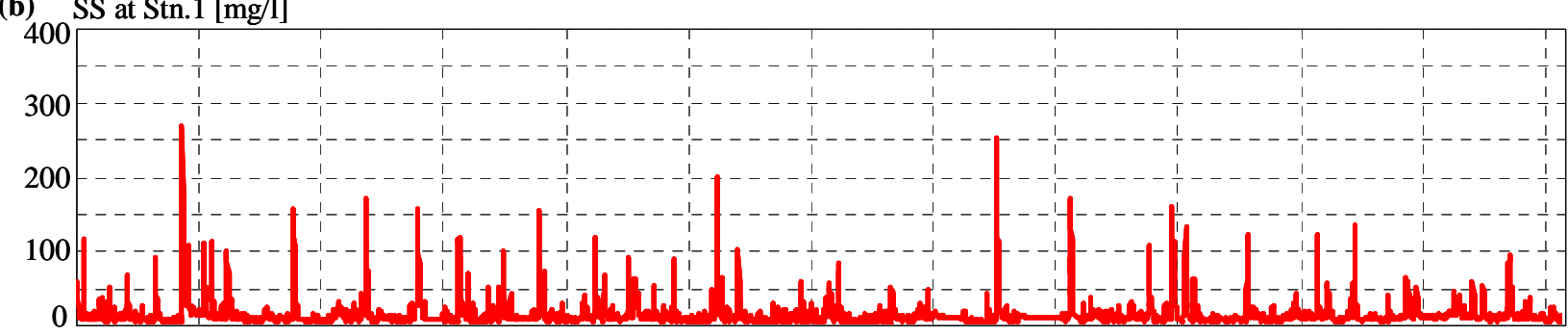

(c) SS at $\operatorname{Stn} .3[\mathrm{mg} / \mathrm{l}]$

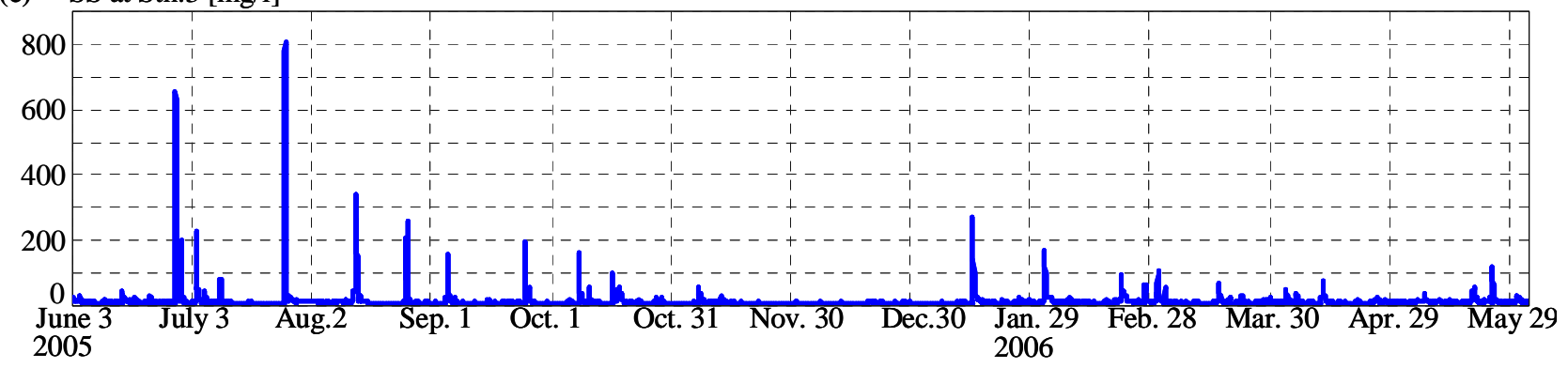

図-2 Stn.1 における流量 $Q(\mathbf{a})$ と $\mathrm{SS}(\mathbf{b})$ 及び Stn.3 における $\mathrm{SS}(\mathbf{c})$ の時間変化 


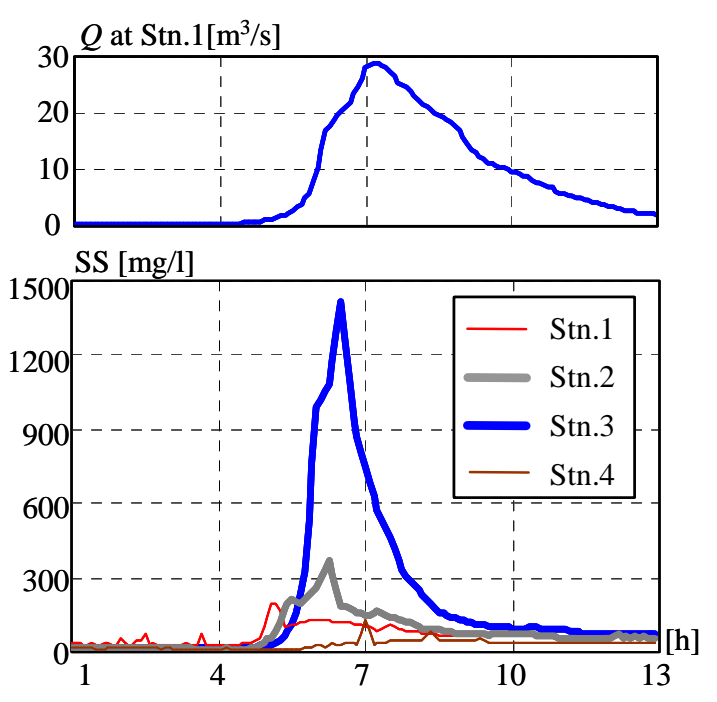

図-3 降雨イベント時における SS 変化の一例 (降雨 イベント(2)，2005年 7 月 26 日)

上流側の Stn. 1 と下流側の Stn.3 における SS を見 ると, 両地点ともに降雨イベント時には SS は増加 するが, 弚の樣子は大きく異なる.具体的には, 年 最大 SS については, Stn.1 では降雨イベント(1)にお いて現れ，弚の大きさは $270 \mathrm{mg} / 1$ である .一方 , Stn.3 では，降雨イベント(2)において， 800mg/l の年最大 SS か観測されている．また，Stn.3 においては，降 雨時の SS は夏期 (6月から 8 月) の方が产の他の期 間よりも大きくなっているが, Stn.1 においてはとの ような季節的な違いは明確ではない．さらに，Stn.1 における SS は, 降雨時を含めて細かい変化が見ら れるが,Stn.3では光のような特徵は観測されていな い.このように，上流側（Stn.1）と下流側 (Stn.3) における SS 環境が異なる樣子は, 降雨イベント毎 の短い時間スケールから季節毎の長い時間スケール まで生じていることが示された .

\section{（２）SSフラックスの比較}

一般観測点 (Stn.1) と接続点 (Stn.3) における SS フラックスについて, 降雨イベント毎, 月毎, 年間 という樣々な時間スケールで比較することを試みる . a) 降雨イベント毎

降雨イベント時における SS 変化の一例として， 年最大流量が観測された降雨イベント(2)における河 川内 (Stns.1〜3) 及び沼内 (Stn.4) における SS の 時間変化を図-3 に示す. 河川内では, Stns.1 と 2 に 比べ Stn.3 の SS が大きい . Stn.1 から Stn.3 の間では 横流入がないことから，この降雨時では Stn.2 から Stn.3 において河床堆積物の巻上げプロセスか顕著 であったものと考えられる . また , 沼内 (Stn.4) の SS は, 河川内よりも小さく, 接続点より流出した懸

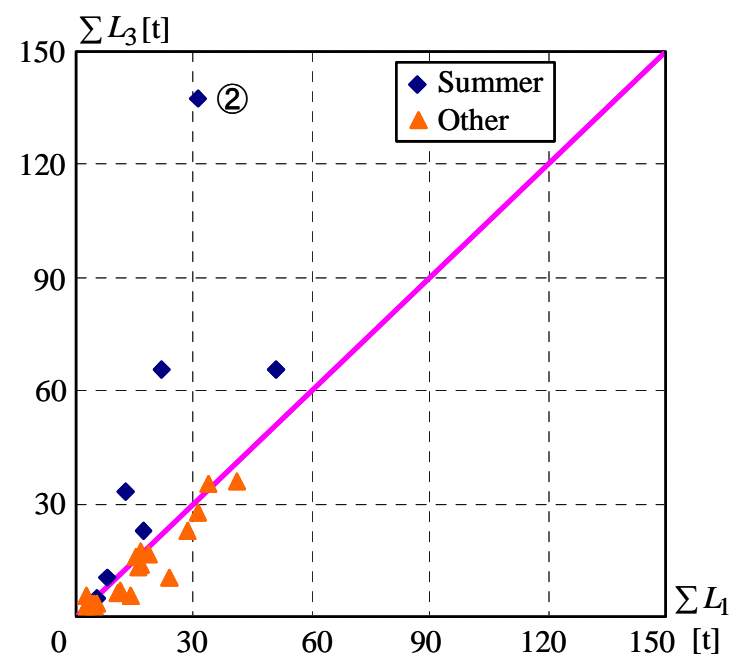

図-4 Stns.1 と 3 における各降雨イベント時の累積 $\mathrm{SS}$ フラックス $\sum L_{1}, \sum L_{3}$ の比較 (夏期 (6〜8 月) と 兴の他の時期を分けて表示)

\section{濁物質の大部分は接続点近傍に沈降している .}

降雨イベント時における累積 SS フラックス $\sum L$ (各イベント中の SS フラックスの積算值) を比べ るために, Stn.1 と Stn.3 の累積值 $\sum L_{1}, \sum L_{3}$ の相 関図を図-4に示す.ここでは, 全観測期間中に生じ た 28 の降雨イベントを対象として,夏期 (2005 年 6 月〜 8 月， $\mathrm{n}=8)$ と兴の他の期間 $(\mathrm{n}=20)$ に分けて 表示している.これを見ると，夏期のケースに関し ては , 全体的に Stn.3 の累積 SS フラックスが大きく なっている．弚の中でも，最も差が大きいのは降雨 イベント(2)における結果である. 弚れに対して，光 の他の期間では，夏期とは反対に，全体的に Stn.1 の累積 SS フラックスが大きい.より定量的に比べ るために, 降雨イベント毎に両地点間の累積 SS フ ラックスの相対差 $\Delta L \quad\left(=\left(\sum L_{3}-\sum L_{1}\right) / \sum L_{1} * 100\right)$ を求めたところ，夏期では-44〜342\%，关の他の期 間では-60〜 $125 \%$ となり，相対差は両者共に大きい． このように，降雨イベント毎では，一般観測点と接 続点における流入負荷量が同一ではなく，光の差が 非常に大きいことが分かる .

降雨イベント時における累積 SS フラックス差に ついて検討する . 河川下流域の土砂輸送過程が水理 条件に大きく依存することに着目して ${ }^{4)}$, 降雨イベ ント時の最大流量 $Q_{\max }$ と累積 SS フラックス差 $\sum L_{3}-\sum L_{1}$ の相関図を図-5 に示す .この累積 SS フ ラックス差が正の場合は対象区間で侵食傾向が , 負 の場合は堆積傾向が卓越することを意味する．これ より，夏期では，累積 SS フラックス差は正となる ケースが多いのに対して，兴の他の期間ではフラッ クス差は負となる傾向が見られる . また, 同じ最大 流量 $Q_{\text {max }}$ における累積 SS フラックス差は , 夏期の 


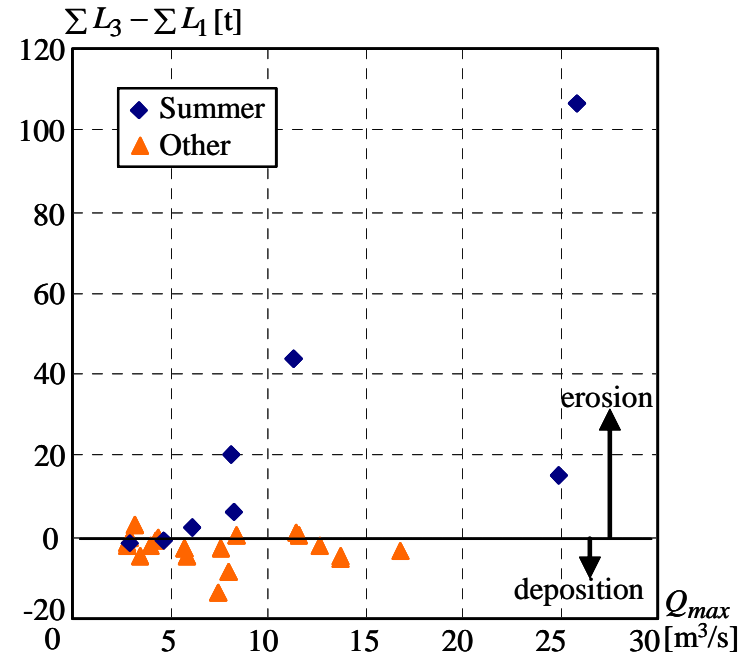

図- 5 各降雨イベント時における最大流量 $Q_{\max }$ と 累積 SS フラックス差 $\sum L_{3}-\sum L_{1}$ の比較

方が兴の他の期間よりも大きい．これより，同程度 の出水規模でも，時期により，大堀川下流域におけ る侵食・堆積特性が変化することが示された .この 要因の一つとして, 底質の巻上げ特性が季節的に変 化することが予想され，現在，別途検討中である . b) 月毎

Stns. 1 と 3 における累積 SS フラックスを月毎に算 出した結果を図-6に示す．これを見ると，夏期 (6 〜8 月)では Stn.3の SS フラックスが Stn.1 の結果よ りも大きいのに対して, 兴の他の期間では, 弚の逆 となっており，降雨イベントにおける累積 SS フラ ックスの関係と対応している．また, 大きな降雨イ ベントが見られなかった 2005 年 $11 ， 12$ 月，2006 年 4 ,5月においては Stn.1 の累積 SS フラックスがStn.3 の値よりも大きくなっている .これより, 非降雨時 においても，両地点間には SS フラックスの差が生 じていることが分かる .

月毎の相対差 $\Delta L$ を求めると，夏期では $21 〜 115 \%$, その他の期間では-48〜-7\%と $\Delta L$ は大きく，光の傾 向は大規模な降雨イベントが生じた夏期において特 に顕著となる このように，月スケールで見た場合， Stn. 1 と Stn.3 の累積 SS フラックス差は大きく，光の 傾向は降雨影響が強い夏期において明確となる .

c) 年間

1 年間にわたる累積 SS フラックスの時間変化を 図-7 に示す .ここでもStns.1 と 3 の結果が表示され ている.累積 SS フラックスは, 両地点ともに, 降 雨時に急激に, 非降雨時では緩やかに光れ光れ増加 する. 両地点における累積 SS フラックスを比べる と, 観測開始直後は概ね同一であるが，降雨イベン ト (2)の後では Stn.3 の累積值が Stn.1 よりも顕著に大

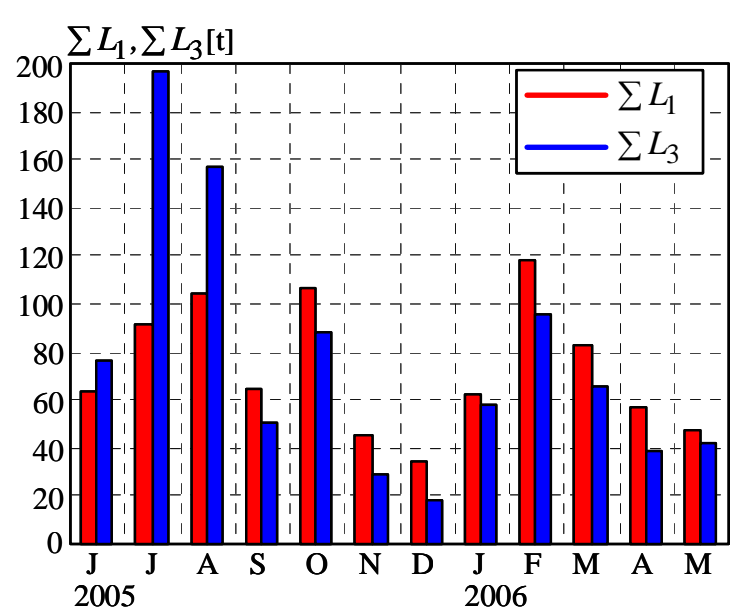

図-6 各月の累積 SS フラックスの比較 (2005 年 6 月から 2006 年 5 月までの 1 年間)

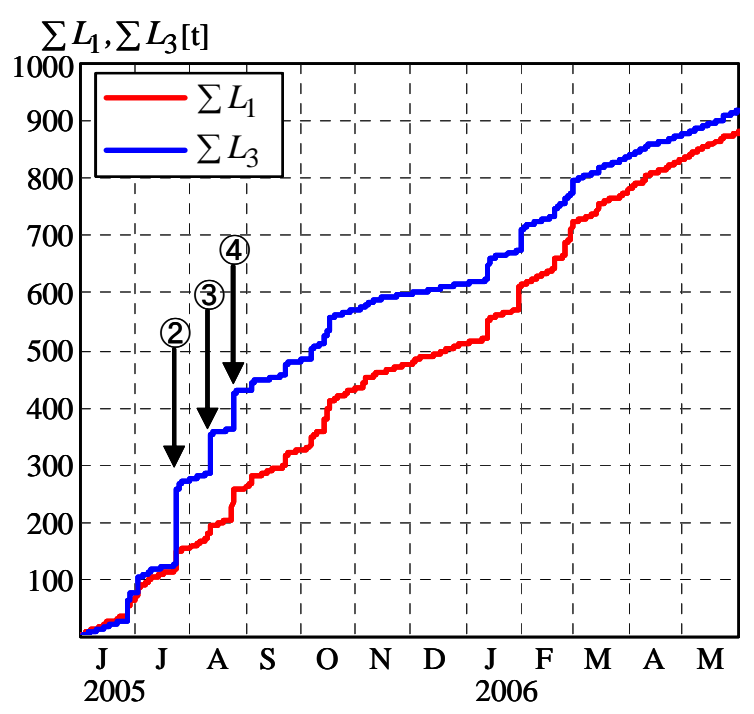

図-7 Stns.1 と 3 における累積 SS フラックス $\sum L_{1}$ ， $\sum L_{3}$ の時間変化 (2005 年 6 月から 2006 年 5 月まで)

きくなる. 8 月の降雨時(3)，(4)にて両者の差は広が るものの, 兴の後の期間では両者の差は減少する .

図-8 は, 1 年間の累積 SS フラックスを降雨時と 非降雨時に分けて表示したものである.年間 SS フ ラックスは ,Stn.1 では 878t ,Stn.3では 916t となり， 両者の差は $38 \mathrm{t}$ である . このときの相対差 $\Delta L$ は $4 \%$ と非常に小さく,Stns.1 と 3 における年間 SS フラッ クスはほぼ同一である。これを降雨時, 非降雨時別 に見ると，Stn.1では降雨時 $454 \mathrm{t}$ ，非降雨時 $424 \mathrm{t}$ と ほぼ同程度である .一方, Stn.3 では降雨時 594t, 非 降雨時 $323 t$ となり, 降雨時の占める割合が高い . ま た, 非降雨時では Stn.1 の方が $101 \mathrm{t}$ 大きいのに対し て，降雨時では Stn.3 の方が $139 t$ 大きい .これより， 非降雨時に下流域に堆積した土砂が降雨時に再懸濁 させられ，年間スケールで見ると土砂堆積量と再懸 濁量がほぼ同一であると言える。 


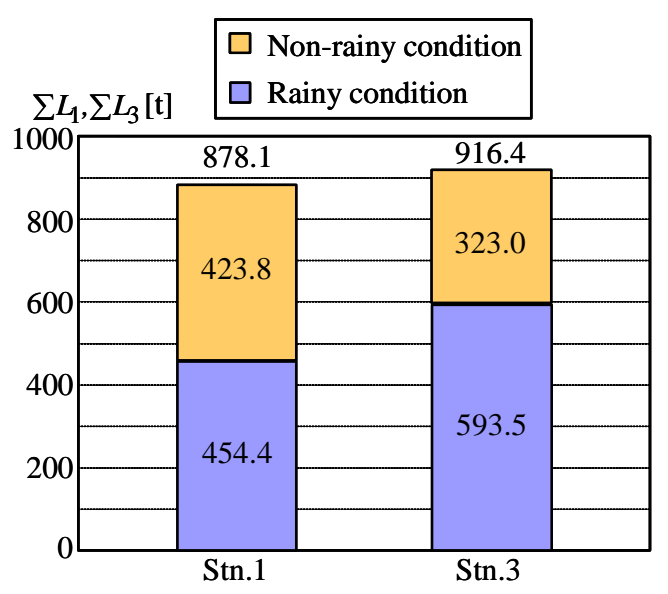

図-8 年間 SS フラックスの比較 (図中の数字は,上か ら全体 , 非降雨時, 降雨時の SS フラックスを示す)

以上の結果から，降雨イベント毎や月毎における SS フラックスは一般観測点 (Stn.1) と接続点 (Stn.3) では同一とならないが, 年間スケールでは両者の結 果はほぼ一致する .このことより, SS の場合 , 「一 般観測点（Stn.1）と接続点（Stn.3）における流入負 荷量が同一である」という仮定は，相対的に短い時 間スケール (降雨イベント, 月) では大きな誤差を 生むものの，長い時間スケール (年) では概ね妥当 であることが明らかとなった .さらに, 土砂濃度と 栄養塩・有機物の懸濁態濃度の相関性が概ね良いの で，土砂輸送特性で得られた知見を懸濁物質の流入 負荷特性に準用することは可能であると考えられる．

\section{4. 底質巻上げ量の取り扱いに着目した土砂輸 送シミュレーション}

\section{（１）着目点と計算諸条件}

河川下流域における土砂動態を考慮した流入負荷 モデルを構築するに当たり，降雨イベント時に卓越 する底質巻上げ量に着目する . 底質巻上げ量 $P_{k}$ は, 一般に底面せん断力 $\tau$ のべき関数 $\left(P_{k}=a\left(\tau-\tau_{c}\right)^{b}\right.$ ， $\tau_{c}$ : 限界せん断力, $a, b:$ 係数) として与えられる. 係数 $a, b$ は場所毎・時間的に変化することが予想さ れるが，光の実態は不明であり，経験的に設定され る.一例として, 大堀川下流域 5 地点における底質 巻上げ量 $P_{k}$ と底面せん断力 $\tau$ の相関図を図- 9 に示 す.これは現地直接計測型巻上げ装置9)による計測 結果 (2005 年 11 月 1 日) であり, 計測地点は接続 点の上流側 $0.4,0.5,0.6,1.2,1.5 \mathrm{~km}$ の 5 地点であ る.ここでの河床材料の中央粒径はおよ光 200〜 600 $\mu \mathrm{m}$ であるのに対して, 巻上げ装置内において浮遊 した土砂の中央粒径はこれより1オーダー小さい 10) .この図より，河川下流域では底質巻上げ特性が

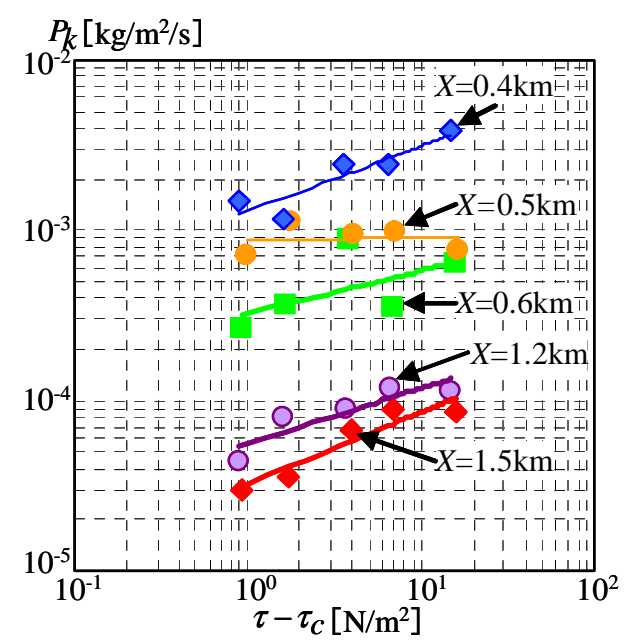

図-9 巻上げフラックス $P_{k}$ と底面せん断力の関係 (2005 年 11 月 1 日, 図中の $X$ は接続点 (Stn.3) か らの縦断方向距離を示す)

空間的に非一樣であり，同一の底面せん断力でも 1 オーダー以上 $P_{k}$ が変化する .この底質巻上げ量の取 り扱いに着目して浮遊土砂輸送計算を行う.

用いる数值モデルは, 河道平面形状を合理的に表 記する水平 $\sigma$ 座標系に基づく平面二次元河川流モデ ルである ${ }^{11)}$. 計算領域は, 大堀川下流域の Stn.1 か ら $\operatorname{Stn} .3$ までである.計算期間は, 上記の底質巻上 げ調査を行った時と最も近い降雨イベント時 (2005 年 11 月 6〜7日) とし, 単一粒径の浮遊土砂輸送の みを対象とする．底質巻上げ量の取り扱いが土砂輸 送量の計算結果に及ぼす影響を検討するために，底 質巻上げ量 $P_{k}$ の空間変化と計算格子解像度に着目 する.まず，格子数 $48 \times 43,5$ 地点の実測巻上げ量 を与える条件を Case1 (基準) とする．次に，格子 解像度は Case 1 と同じとし, 巻上げ量として 2 地点 $(X=0.6,1.5 \mathrm{~km})$ の結果を与える条件 (Case2) と 1 地点 $(X=1.5 \mathrm{~km})$ のみの結果を採用するケース (Case3) を設定する . また，巻上げ量の与え方は Case1 のままで, 横断方向格子数を変える 2 ケース

(Case4：48× 17，Case5：48×5) を設定する.

\section{( 2 ) 計算結果}

図-10 は Case1，2，3 における Stn.3 の SS の計算 結果及び観測結果を示す . 図中には, Stn.1における 流量の計算結果も表示している．これより，3 ケー スの計算結果のうち，巻上げ量の空間分布を最も詳 細に考慮した Case1 の結果が観測値に最も近くなっ ている．また，空間分布を全く考慮しない Case3 の 計算結果は，観測值との差が最も大きい .

各ケースの計算結果から累積 SS フラックスを算 出し, 光の結果と観測値から求めた相対誤差 $\operatorname{Err}(=$ (観測値 - 計算值) /観測值*100）を表-1 に示す. 
(a) $Q$ at $\operatorname{Stn} .1\left[\mathrm{~m}^{3} / \mathrm{s}\right]$
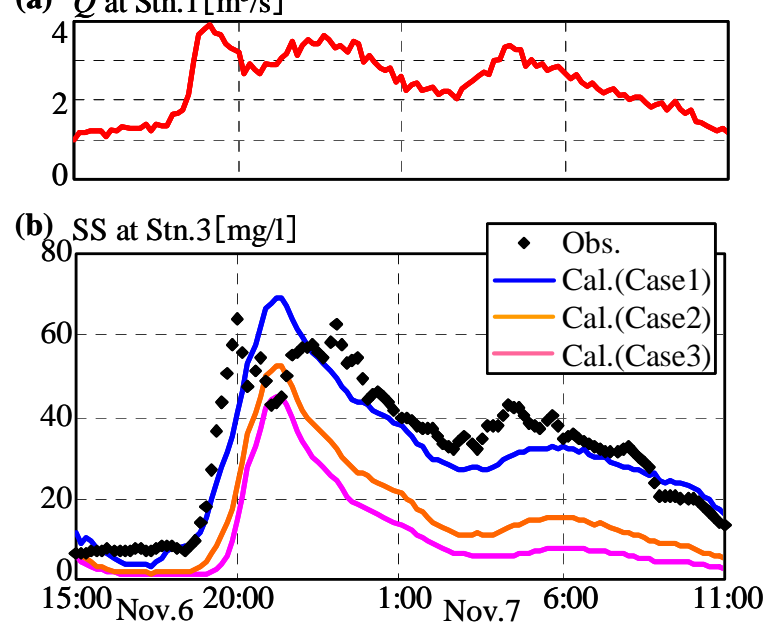

図-10 Case1，2,3における計算結果と観測結果の比 較 (Stn.1 の流量(a)と Stn.3の SS(b)を示す)

表-1＼cjkstart累積 SS フラックスの相対誤差 $E r r$

\begin{tabular}{|c||c|}
\hline No. & Err [\%] \\
\hline Case 1 & 7.4 \\
\hline Case2 & 48.9 \\
\hline Case3 & 65.5 \\
\hline Case4 & 13.7 \\
\hline Case5 & 21.5 \\
\hline
\end{tabular}

上述した Case1，2，3では，相対誤差 Err は 7，49， $66 \%$ となり，巻上げ量の空間分布を実態に則してい ない Case2 や Case3 では計算誤差が非常に大きい . また 横断方向格子数を変えた Case4 と Case5 の Err は $14,22 \%$ となり, 格子解像度が粗くなると計算誤 差も増える.これは, 格子解像度を変化させると流 速横断分布の再現性が悪くなり，底面せん断力の評 価精度が低下するためである .このように, 河川下 流域における懸濁物質フラックスを高精度に評価す る上では，底質巻上げ量や底面せん断力を精度良く 評価することが必要である，弚のためには，実測デ 一タに基づいて底質巻上げ量を評価するとともに． 流速横断分布を正確に表すのに必要な格子解像度を 確保することが必須である .

\section{5. 結論}

富栄養化湖沼の流入負荷特性の実態や炎の計測法 を検討するために，手賀沼の主要流入河川である大 堀川下流域を対象として, 1 年間の土砂輸送量モ二 タリング及び底質巻上げ量に着目した土砂輸送計算 を実施した . 得られた結論は次のとおりである .

(1) 上流側の一般観測点 (Stn.1) と下流側の接続 点 (Stn.3) における SS フラックスを樣々な時間ス
ケールで比較した . 炎の結果, 降雨イベントや月と いう相対的に短い時間スケールでは，両地点におけ る SS フラックスの差は非常に大きいのに対して , 両地点の年間 SS フラックスはほぼ一致していた .

（2）このような観測結果より，流域から河川経由 で湖沼へ流入する懸濁態物質の総負荷量評価に対し て，一般観測点におけるモニタリング結果を準用す ることは, 年間負荷量については問題ないものの， 降雨イベント毎や月間の総負荷量に関しては大きな 誤差を生むことが明らかとなった .

（３）河川下流域の土砂動態を考慮した形で流入負 荷モデルを構築するには，河床における底質巻上げ 量や底面せん断力の高精度評価が極めて重要である， 弚のためには，底質巻上げ量の空間分布を適切に与 え，また十分な格子解像度を確保する必要がある。

謝辞：現地調査の実施には，東京理科大学理工学部 土木工学科水理研究室学生諸氏には御助力を頂いた . 本研究の一部は, 科学研究費補助金基盤研究 (C)

（2） (研究代表者：二瓶泰雄）によるものである. ここに記して謝意を表する。

\section{参考文献}

1) 岩佐義朗 : 湖沼工学, 山海堂, pp.455-504, 1990 .

2) (社) 日本河川協会編 : 建設省河川砂防技術基準 (案) 同解説，山海堂，pp.329-384，1997.

3) Fukushima, T., Aizaki, M. and Ebise, S.: Dynamics of particulate matter near the mouth of influx river in Takahamairi Bay of Lake Kasumigaura with special reference to nitrogen and phosphorus, Jpn. J. Limnol., Vol.52, No.1, pp.13-26, 1991.

4) 山口 裕介, 二瓶泰雄, 大関雅丈, 今野篤, 西村司 : 都 市河川河口域における土砂・栄養塩・有機物輸送特性 に関する現地観測，水工学論文集，Vol.48， pp.1489-1494, 2004 .

5) 海老瀬潜一: 污濁物質の降雨時流出特性と流出負荷量， 水質污濁研究, Vol.8, No.8, pp.31-36, 1985 .

6) 大久保卓也 : 懸濁態リンの生物利用可能性, 用水と廃 水, Vol.38, No.3,pp.34-46, 1996 。

7) 山田安彦, 白鳥孝治, 立本英機：印旛沼 - 手賀沼 - 水環境への提言 - , 古今書院, pp.1-167, 1993 .

8) (社) 日本下水道協会 : 下水試験方法上巻 -1997 年 版 - , pp.136-201, 1997 .

9) 二瓶泰雄 , 山口 裕介, 西村司, 丸山透 : 都市河川にお ける易浮遊性堆積物環境の検討, 水工学論文集, Vol.48,pp.1447-1452, 2004 .

10）福地正宗, 二瓶泰雄 , 大関雅丈 : 底質巻上げ計測デー タに基づくウォツシュロードの供給源に関する一考 察, 土木学会年次学術講演会講演概要集第 2 部,Vol.61, pp.526-527, 2006 .

11）山口裕介, 二瓶泰雄, 大関雅丈 : 河川 - 湖沼結合モデ ルに基づく手賀沼における土砂輸送シミュレーショ ン, 水工学論文集, Vol.49, pp.1225-1230，2005.

( 2006. 9. 30 受付) 